Journal of Agriculture, Food and Environment (JAFE)

Journal Homepage: http://journal.safebd.org/index.php/jafe

http://doi.org/10.47440/JAFE.2021.2309

Original Article

\title{
Comparative Profitability of Conventional and Chemical Free Pineapple Production in Madhupur Upazila of Tangail District
}

\author{
N. I. Nishat $^{1 *}$, J. I. Islam ${ }^{1}$, M. A. Mou ${ }^{2}$ \\ ${ }^{1}$ Department of Agricultural Economics, Bangladesh Agricultural University, Mymensingh-2202 \\ ${ }^{2}$ Department of Animal Breeding and Genetics, Bangladesh Agricultural University, Mymensingh-2202
}

\section{A B S T R A C T}

\section{Article History}

Received: 21 July 2021

Revised: 19 September 2021

Accepted: 22 September 2021

Published online: 30 September 2021

\section{*Corresponding Author}

N. I. Nishat, E-mail:

nazneennishat@bau.edu.bd

\section{$\underline{\text { Keywords }}$}

Pineapple; comparative profitability; Logistic regression model; Madhupur Upazila.

\begin{abstract}
The purpose of this study was to determine the relative profitability of nonadopters and adopters, as well as the factors influencing the adoption of chemical-free pineapple production technology at Madhupur Upazila Tangail district. Data were collected by interviewing 50 randomly selected pineapple producers of Haludiya, Baniabari and Aushnara villages of Madhupur Upazila in Tangail during July to September 2019. For comparing the profitability of chemical-free and conventional pineapple farming, two groups of pineapple growers were chosen: non-adopters and adopters. Farmers were chosen from two groups using a purposive sampling strategy. Collected data were analyzed with undiscounted BCR and logistic regression analysis. Per acre total cost were estimated Tk. 16,5477 and Tk.16,4285.66, respectively for non-adopters and adopters of chemical free pineapple production. The per acre gross returns of pineapple were determined in this study at Tk. 31,7995.2 for non-adopters and Tk. 40,2986 for adopters of chemical-free pineapple producing technology. Gross margin per acre was estimated Tk. 16,1518.2 for non-adopters and Tk. $24,6700.35$ for adopters, respectively. Thus, the net return per acre were Tk. 15,2518.2 for non-adopters and Tk. 23,8700.34 for adopters of chemical free technology of pineapple production. The undiscounted Benefit Cost Ratio on the basis of total cost was 1.92 for non-adopters implying that Tk. 1.92 would be earned by investing every Tk. 1.00 in conventional pineapple production and BCR was estimated 2.45 for adopters implying that Tk. 2.45 would be earned by investing every Tk. 1.00 in chemical free pineapple production. Binary Logit regression estimate suggest that ethnicity and gross margin had a substantial impact on the adoption of this chemical-free technology. The majority of the farmers had a relatively good attitude toward chemical-free pineapple cultivation, according to the results. Extension agents must increase their contact with farmers in order to effectively disseminate information about chemical-free pineapple farming. Overall, it can be summarized that this paper has found that total costs of production is higher for conventional pineapple growers; however, gross return is higher for the chemical-free pineapple growers. This implies that chemical-free pineapple is profitable in contrast to conventional pineapple, which has further been proved the undiscounted BCR.
\end{abstract}

(C) 2021 The Authors. Published by Society of Agriculture, Food and Environment (SAFE). This is an Open Access article distributed under the terms of the Creative Commons Attribution 4.0 License (http://creativecommons.org/licenses/by/4.0)

\section{Introduction}

Pineapple (Ananascomosus) is a globally popular fruit because of its pleasant flavor, exquisite taste, high nutritional and therapeutic benefits. Pineapple is one of the most important commercial fruit crops in the world and is being grown in about 90 countries of the world. In Bangladesh,
Pineapple is a popular fruit and it is ranked third in terms total production and area farmed, both of which are increasing continually (BBS, 2018). It provides a variety of vitamins, carbs, crude fiber, water, and minerals that are beneficial to the digestive system and aid in the maintenance of a healthy weight and balanced diet. Pineapple is low in 
fat, sodium and contains vitamin A (Sabahelkhier et al. 2010). The fruit is commonly consumed both fresh and in juice form. In Bangladesh, three varieties Giant Kew, Honey Queen, and red Spanish (Ghorashal) are widely planted, mainly in terraced and steep areas like Tangail, Sylhet, Chittagong, Comilla districts and Chittagong Hill Tracts. Specially, the 'Giant Kew' variety, locally known as Bandarban, has proven to be well adapted to local environmental circumstances as well as local and export preferences, being larger, juicier, and sweeter than varieties grown in other parts of the country. A total of 45,685 acres of land is being used for pineapple production, with a total production of 0.23 million MT (Proshad et al., 2018). The use of agrochemicals has increased with introduction of modern agriculture (Joy and Sindhu, 2012). Unfortunately, farmers are unaware of the dangers of agro-chemicals and use them according to the advice of agro-chemical dealers. From the time of planting till fruit harvest, at least ten different pesticides and insecticides are said to be used. Farmers also apply particular chemicals to help with artificial ripening and delayed decay. This tendency of using chemicals to increase its production is ruining the legendary taste of pineapple. This tactic has been observed in pineapple production in Madhupur Upazilla of Tangail district, and it is a severe concern for food safety and public health (Mursalat et al., 2013). According to environmentalists, farmers do this because they lack sufficient information and want to make a little extra money. Non-optimal and judicious use of agrochemicals (which are toxic in nature or lethal when used at high doses) can harm the environment and pose a health risk to both growers and consumers (Proshad et al., 2018). The purpose of this study was to compare the profitability of non-adopters and adopters of alternative chemical-free pineapple production approach in Madhupur Upazila of Tangail, as well as to find the factors influencing adoption of this alternative technology.

\section{Materials and Methods \\ 2.1 Study Area}

Tangail is a district in Bangladesh's central region and it has 12 Upazilas. Madhupur being one of the Upazilas covers land area of 332.13 square kilometers, located in between $24^{\circ} 47^{\prime}$ and $24^{\circ} 31^{\prime}$ north latitudes and in between $90^{\circ} 10^{\prime}$ and $89^{\circ} 57^{\prime}$ east longitudes. It has a large forest area named 'Madhupur Sal Forest". The total cultivable land area is 32900 hectares, including 2000 hectares of fallow land (BBS, 2018).

Farmers of Madhupur Upazila grow a variety of crops, the major crops being rice, jute, cotton, potato, pointed gourd, ginger, cassava, vegetables, pineapple, banana, jackfruit, litchi and papaya. About $70 \%$ of the country's pineapple are grown in Madhupur area. Mango, jackfruit, pineapple, papaya, litchi, and olive are the main fruits. Pineapple, jackfruit, silk, cassava, cotton, and honey are among the main agricultural exports. Based on the intensity of pineapple production, agroecology and accessibility, the study area was selected in Madhupur Upazila and study area consisted of three villages-Haludiya, Baniabari, and Aushnara. These three villages are located in the northeast of Tangail region.

\subsection{Sampling Procedure and Sample size}

For comparing the profitability of chemical-free and conventional pineapple farming, two groups of pineapple growers were chosen: non-adopter farmers and adopter farmers. Farmers were chosen from two groups using a purposive sampling strategy. For collecting data, 50 farmers were chosen (25 non-adopters and 25 adopters) [Table 1]. These farmers were divided into three categories based on the size of their holdings: small farmers (0.1-2.49 acres), medium farmers (2.50-7.49 acres), and large farmers (above 7.50 acres).

\subsection{Data collection and processing}

Pineapples are typically planted in February or March and harvested between June and August. As a result, the data were collected from July to September 2019 using a pretested interview schedule. Direct interviews were conducted by the researcher, who made personal visits to the households of the selected individual farmers. The data were entered using a spread sheet in MS Excel including the responses of the respondents captured in the questionnaire. There were qualitative data which were first coded and then transformed into a quantitative format for the purpose of analysis.

\subsection{Activity budgets}

The most frequent way for determining and comparing the profitability of enterprise operations undertaken by concerned farmers while taking into consideration various production strategies is to use an activity budget. Cost items of selected farming practices were classified into two major groups, such as: (a) fixed costs and (b) variable costs. The profitability of chemical free and conventional pineapple production was found in terms of gross return, gross margin, net return and benefit cost ratio (undiscounted). The difference between total revenue and total expense is described as profit. The following algebraic profit $(\boldsymbol{\pi})$ equation was employed to prepare activity budgets of the concerned selected pineapple production in conventional technique and chemical free technique.

$\pi=$ TR-TC

where, $\mathrm{TR}=$ Total return

$\mathrm{TC}=$ Total Cost

\section{Gross return/Total return}

Gross return was calculated by multiplying the total volume of output of an enterprise by the average price in the harvesting period (Dillon and Hardaker, 1993). To calculate $\mathrm{GR}$, the following equation was used:

Gross return, $\mathrm{GR}=\mathrm{Q} \times \mathrm{P}$

Where, GR= Gross return $(\mathrm{Tk}) ; \mathrm{Q}=$ Quantity of the product(piece) $; \mathrm{P}=$ Average price of the product(Tk);

\section{Gross margin}

The gross return of an agricultural farm less the variable costs associated to it is the gross margin (GM) (Barnard and Nix, 1999). The difference between gross return and variable costs is used to compute gross margin.

That is, Gross margin, GM=GR - TVC

Where, GM=Gross margin(Tk); GR=Gross return(Tk); TVC= Total Variable cost $(\mathrm{Tk})$.

\section{Net return}

Total costs (variable and fixed) were subtracted from the gross return to arrive at the net return.

Net return, $\mathrm{NR}=\mathrm{GR}-\mathrm{TC}$

Where, GR= Gross return (Tk.) and $\mathrm{TC}=$ Total cost $(\mathrm{Tk}$. 


\section{Benefit Cost Ratio (BCR)}

Benefit cost ratio (BCR) is calculated by dividing gross return by gross cost. It is a ratio and unit free.

$\mathrm{BCR}=$ Gross Benefit/Gross Cost

\subsection{Econometric model}

Binary Logit model expresses a qualitative dependent variable as a function of several independent variables, both qualitative and quantitative. The Logit model was used to determine the factors that influence the adoption of chemical free pineapple production adoption.

Empirical model formulation:

The explicit form of the model is as follows:

$\mathrm{Y}=\log \left(\frac{P}{P-1}\right)=\mathrm{b}_{0}+\mathrm{b}_{1} \mathrm{X}_{1}+\mathrm{b}_{2} \mathrm{X}_{2}+\mathrm{b}_{3} \mathrm{X}_{3}+\mathrm{b}_{4} \mathrm{X}_{4}+\mathrm{b}_{5} \mathrm{X}_{5}+$

$\mathrm{b}_{6} \mathrm{X}_{6}+e$

where,

$\mathrm{P}$ is the dichotomous dependent variable which represents the probability of non-adoption and adoption of chemical free production;

$P=0$ indicates non-adoption and $P=1$ indicates adoption.

$X_{1}=$ Age of the respondent (years); $X_{2}=$ Ethnicity; $X_{3}=$ Education level of the respondent (number of years); $X_{4}=$ Farm size (acre); $X_{5}=$ Farm income (Tk.); $X_{6}=$ Training days; $b_{0=}$ Intercept.

$b_{1}, b_{2}, b_{3}, b_{4}, b_{5}, b_{6}$ are regression coefficients of the dependent variable;

$\mathrm{e}=$ Disturbance term or error term.

\section{Results and Discussion}

One of the most crucial components of this research was assessing the profitability of pineapple cultivation using both conventional and chemical-free methods. Calculating net return and gross margin was a quick approach to analyze profitability. The cost of production and subsequently the value of gross return have been computed to get the value of net return. Activity budgets are shown in table 1 and 2 .

Table 1. Distribution of sample farmers.

\begin{tabular}{lcccc}
\hline \multicolumn{1}{c}{ Farm Size } & \multicolumn{2}{c}{ Non-adopters } & \multicolumn{2}{c}{ Adopters } \\
\cline { 2 - 5 } & No. & Percentage (\%) & No. & Percentage (\%) \\
\hline $\begin{array}{l}\text { Small Farmer } \\
\begin{array}{l}\text { (0.1-2.49 acres) } \\
\text { Medium Farmer }\end{array}\end{array}$ & 16 & 64 & 4 & 16 \\
$\begin{array}{l}\text { (2.50-7.49 } \\
\text { acres) }\end{array}$ & 36 & 15 & 60 \\
$\begin{array}{l}\text { Above 7.50 } \\
\text { acres }\end{array}$ & 0 & 0 & 6 & 24 \\
Total & 25 & 100 & 25 & 100 \\
\hline
\end{tabular}

Source: Authors' estimation, 2019.

Table 2. Activity budgets: per acre pineapple production of non-adopters of chemical free technology.

\begin{tabular}{lcccc}
\hline \multicolumn{1}{c}{$\begin{array}{c}\text { Items of costs/ } \\
\text { returns }\end{array}$} & $\begin{array}{c}\text { Total } \\
\text { quantity/ } \\
\text { acre }\end{array}$ & $\begin{array}{c}\text { Per unit } \\
\text { price } \\
\text { (Tk./unit) }\end{array}$ & $\begin{array}{c}\text { Costs/returns } \\
\text { (Tk./acre) }\end{array}$ & \% of total \\
\hline $\begin{array}{l}\text { A. Gross Returns } \\
\text { Main product } \\
\text { (Pineapple) }\end{array}$ & 12590 pieces & 17.28 & 217555.2 & 68.41 \\
By-product & 50220 pieces & 2 & 100440 & 31.59 \\
Total returns & - & - & 317995.2 & 100 \\
B. Gross Costs & & & & \\
C. Variable Costs & & & & \\
Hired Labor & 250 man-days & 300 & 75000 & 45.32 \\
Power Tiller & - & - & 7500 & 4.53 \\
Sucker & 12740 pieces & 1.5 & 19110 & 11.55 \\
Urea & $1200 \mathrm{~kg}$ & 16 & 19200 & 11.60
\end{tabular}

Nishat et al., 2021

\begin{tabular}{|c|c|c|c|c|}
\hline $\begin{array}{l}\text { Items of costs/ } \\
\text { returns }\end{array}$ & $\begin{array}{c}\text { Total } \\
\text { quantity/ } \\
\text { acre }\end{array}$ & $\begin{array}{c}\text { Per unit } \\
\text { price } \\
\text { (Tk./unit) }\end{array}$ & $\begin{array}{l}\text { Costs/returns } \\
\text { (Tk./acre) }\end{array}$ & $\%$ of total \\
\hline$\overline{\mathrm{MOP}}$ & $500 \mathrm{~kg}$ & 11 & 5500 & 3.32 \\
\hline TSP & $500 \mathrm{~kg}$ & 20 & 10000 & 6.04 \\
\hline Gypsum & $200 \mathrm{~kg}$ & 11 & 2200 & 1.33 \\
\hline Cowdung & $4000 \mathrm{~kg}$ & 1.2 & 4800 & 2.90 \\
\hline Fertilizer cost & - & - & 41700 & 25.20 \\
\hline Growth Hormone-I & $\mathrm{ml}$ & - & 1200 & 0.73 \\
\hline $\begin{array}{l}\text { Growth Hormone- } \\
\text { II }\end{array}$ & $\mathrm{ml}$ & - & 350 & 0.21 \\
\hline $\begin{array}{l}\text { Growth Hormone- } \\
\text { III }\end{array}$ & $\mathrm{ml}$ & - & 350 & 0.21 \\
\hline Ethene & $\mathrm{ml}$ & - & 350 & 0.21 \\
\hline $\begin{array}{l}\text { Total Pesticides } \\
\text { Cost }\end{array}$ & - & - & 2250 & 1.36 \\
\hline $\begin{array}{l}\text { Total Operating } \\
\text { Capital }\end{array}$ & - & - & 145560 & 87.96 \\
\hline $\begin{array}{l}\text { Interest on } \\
\text { Operating Capital }\end{array}$ & - & @ 10\% & 10917 & 6.60 \\
\hline $\begin{array}{l}\text { Total Variable Cost } \\
\text { D. Fixed Costs }\end{array}$ & - & - & 156477 & 94.56 \\
\hline Land use cost & - & - & 7000 & 4.23 \\
\hline Capital items & - & - & 2000 & 1.21 \\
\hline Total Fixed Cost & - & - & 9000 & 5.44 \\
\hline E. Total costs & - & - & 165477 & 100.00 \\
\hline $\begin{array}{l}\text { F. Gross Margin } \\
\text { (A-C) }\end{array}$ & - & - & 161518.2 & - \\
\hline $\begin{array}{l}\text { G. Net Return (A- } \\
\text { E) }\end{array}$ & - & - & 152518.2 & - \\
\hline
\end{tabular}

Source: Authors' estimation based on field survey, 2019.

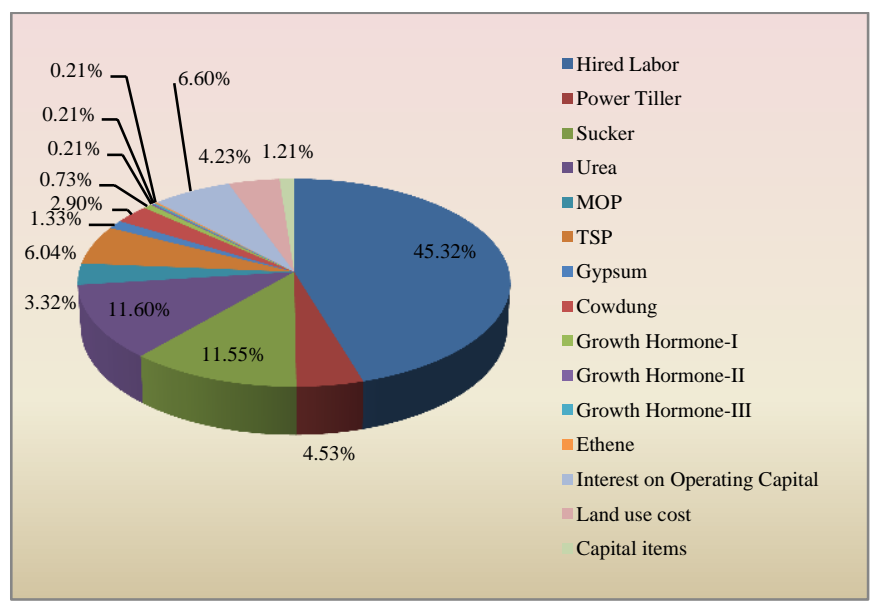

Figure 1. Percentage share of costs for non-adopters of chemical free pineapple production.

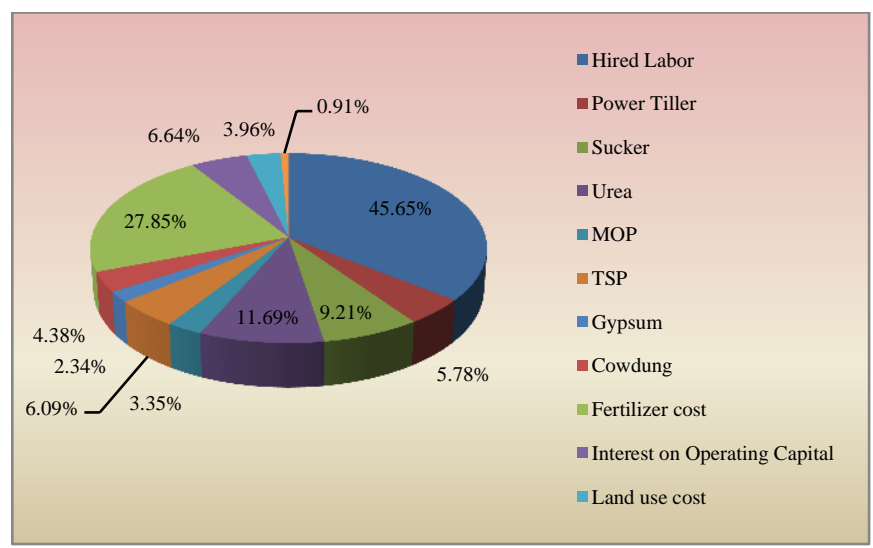

Figure 2. Percentage share of costs for adopters of chemical free pineapple production.

\subsection{Estimation of gross cost}

Costs are the expenses incurred in organizing the production process (Doll and Orazem, 1984). Costs and returns were 
considered from farmers' point of view. The expenses of various farming practices were divided into two categories: (a) fixed costs and (b) variable costs. It primarily focuses on the numerous inputs used in pineapple production, as well as the price of cost items utilized by both non-adopters and adopters of chemical free pineapple production in the study area. Farmers had to pay cash for purchased inputs such as fertilizers, insecticides/pesticides, irrigation water charge and calculating the costs of these goods was rather simple. The average cost of human labour per acre for non-adopters and adopters were estimated Tk. 75000 and Tk. 75000 per acre, respectively which covered 45.32 and 45.65 percent of total cost (Table 2 and 3). In the study area, on an average wage rate was Tk.300 per man-day during the study period. The cost of sucker for non-adopters and adopters were Tk. 19110 and Tk.15132 per acre, respectively which covered 11.55 and 9.21 percent of total cost. Per acre cost of power tiller were found Tk.7500 and Tk.9500, respectively for nonadopters and adopters.

From Table 2 and Table 3 it can also be seen that those nonadopters and adopter of chemical free pineapple production used on an average $500 \mathrm{~kg} / \mathrm{acre}$ and $500 \mathrm{~kg} / \mathrm{acre}$ of Urea, 500 $\mathrm{kg} / \mathrm{acre}$ and $500 \mathrm{~kg} / \mathrm{acre}$ of TSP, $500 \mathrm{~kg} / \mathrm{acre}$ and $500 \mathrm{~kg} / \mathrm{acre}$ of MOP, $250 \mathrm{~kg} / \mathrm{acre}$ and $350 \mathrm{~kg} / \mathrm{acre}$ of Gypsum and 4000 $\mathrm{kg} / \mathrm{acre}$ and $6000 \mathrm{~kg} / \mathrm{acre}$ of Cow dung, respectively. The average price rate of Urea, TSP, MOP, Gypsum and Cow dung were Tk. 16, Tk. 11, Tk. 20, Tk. 11 and 1.2 per kg, respectively. Non-adopter producers paid Tk 2250 per acre for pesticides which was 1.38 percent of the total gross cost. Tk.10,917 and Tk.10,903.65 were estimated as per acre interest on operating capital for non-adopters and adopters, respectively. , covering 6.60 percent and 6.64 percent of the gross cost. The interest on operating capital was computed by taking into account all of the operating expenses incurred during the pineapple production period. It was computed during an 18-month period (considering interest rate 10 percent). Land use cost varies from one part of country to another part of country depending upon soil type, topography, location etc. Considering all the sample farmers, per acre average land use cost was Tk. 7000 for non-adopters and Tk. 6500 for adopters, respectively. In our country land tax is imposed on those farmers whose farm size is greater than 33 bigha, but in the study area the sampled farmer's farm size was less than 33 bigha. That is why the cost of land tax was ignored in the study. Per acre total cost of pineapple production in chemical free approach were Tk. 16,5477 and Tk.16,4285.66, respectively for non-adopters and adopters (Table 2 and Table 3).

Table 3. Activity budgets: per acre pineapple production of adopters of chemical free technology.

\begin{tabular}{lcccc}
\hline $\begin{array}{c}\text { Items of costs/ } \\
\text { returns }\end{array}$ & $\begin{array}{c}\text { Total } \\
\text { quantity/acre }\end{array}$ & $\begin{array}{c}\text { Per unit } \\
\text { price } \\
\text { (Tk./unit) }\end{array}$ & $\begin{array}{c}\text { Costs/ } \\
\text { returns } \\
\text { (Tk./acre) }\end{array}$ & $\begin{array}{c}\text { \% of } \\
\text { total }\end{array}$ \\
\hline $\begin{array}{l}\text { A. Gross Returns } \\
\text { Main product }\end{array}$ & 12600 pieces & 23.63 & 297738 & 73.88 \\
(Pineapple) & & & & \\
By-product & 52624 pieces & 2 & 105248 & 26.12 \\
Total returns & - & - & 402986 & 100 \\
B. Gross Costs & & & & \\
C. Variable Costs & & 300 & 75000 & 45.65 \\
Hired Labor & 250 man-days & - & 9500 & 5.78 \\
Power Tiller & - & 1.2 & 15132 & 9.21 \\
Sucker & 12610 pieces & 16 & 19200 & 11.69 \\
Urea & $1200 \mathrm{~kg}$ & 11 & 5500 & 3.35 \\
MOP & $500 \mathrm{~kg}$ & 20 & 10000 & 6.09 \\
TSP & $500 \mathrm{~kg}$ & & & \\
& & & & \\
\end{tabular}

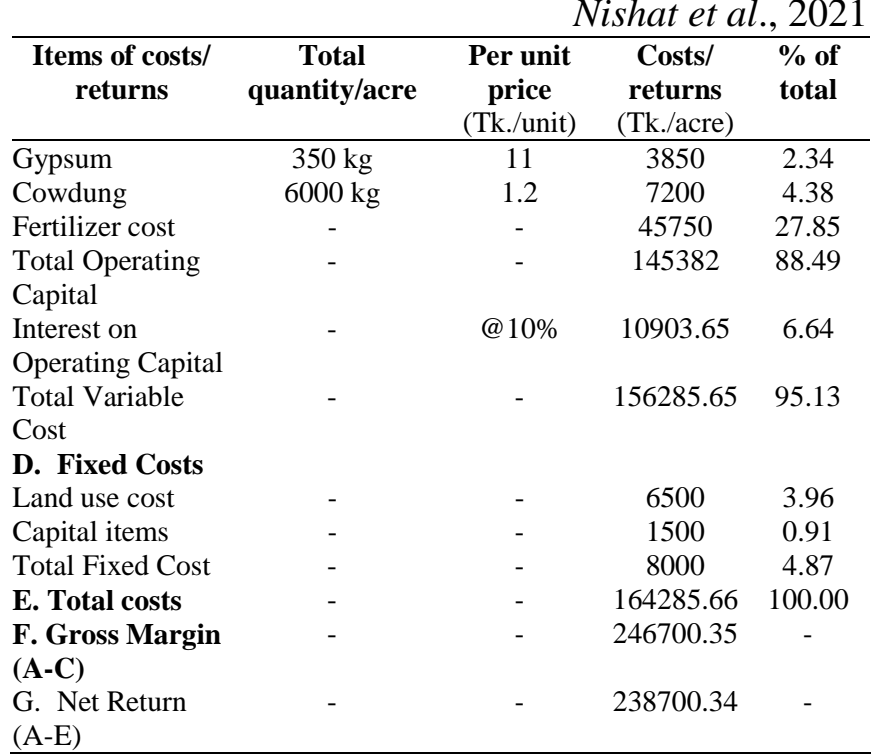

Source: Authors' estimation based on field survey, 2019.

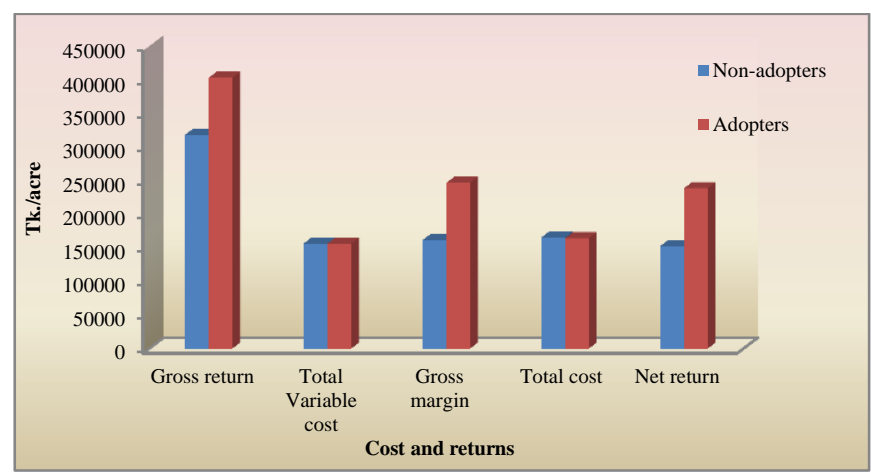

Figure 3. Per acre cost, return, gross margin, net return of non-adopters and adopters chemical free pineapple production.

Table 4. Comparative performance of pineapple production for non-adopters and adopters of chemical free technology in the study area.

\begin{tabular}{lll}
\hline Items & Non-adopters & \multicolumn{1}{c}{ Adopters } \\
\hline A. Gross returns (Tk./acre) & 317995.2 & 402986 \\
B. Total Variable costs (Tk./acre) & 156477 & 156285.65 \\
C. Gross margin (A-B) & 161518.2 & 246700.35 \\
D. Total costs (Tk./acre) & 165477 & 164285.66 \\
E. Net returns (A-D) & 152518.2 & 238700.34 \\
F. Benefit Cost & 1.92 & 2.45 \\
Ratio(A/D)[Undiscounted] & & \\
\hline
\end{tabular}

Source: Authors' estimation based on field survey, 2019.

Table 5. Logistic regression of the factors influencing the adoption of chemical free pineapple production technique.

\begin{tabular}{lcccc}
\hline Variables & $\begin{array}{c}\text { Coefficient } \\
(\boldsymbol{\beta})\end{array}$ & Std. Err. & $\mathbf{z}$ & P value \\
& -2.740446 & 2.785972 & -0.98 & 0.325 \\
Constant & 0.0767371 & 0.0612406 & 1.25 & 0.210 \\
Age $\left(X_{1}\right)$ & $-3.44149 * * *$ & 1.46901 & -2.34 & 0.019 \\
Ethnicity $\left(X_{2}\right)$ & 0.0083192 & 0.0122045 & 0.68 & 0.495 \\
Farm Size $\left(X_{3}\right)$ & -0.00000675 & 0.00000575 & -1.17 & 0.240 \\
Farm income $\left(X_{4}\right)$ & $0.000012 * *$ & 0.00000695 & 1.73 & 0.084 \\
Gross margin $\left(X_{5}\right)$ & 0.1901238 & 0.1181364 & 1.61 & 0.108 \\
Training days $\left(X_{6}\right)$ & 0. & & \\
\hline
\end{tabular}

Source: Authors' estimation, 2019.

Note: $* * *$ indicates significant at 1 percent level; ** indicates significant at 5 percent level. 


\subsection{Estimation of gross return}

Gross return was estimated by multiplying the total amount of product and by product with their respective farm gate prices. Per acre yield of pineapple were 12590 pieces and 12600 pieces and price per piece of pineapple were 17.28 Tk. and 23.63 Tk., respectively for non-adopters and adopters in the harvesting period. In terms of monetary unit, the value of pineapple were Tk. 217555.2 and Tk. 297738, respectively. Total by product value was 100440 Tk./acre and 105248 Tk./acre, respectively. In the present study, per acre gross returns of pineapple were Tk. 317995.2 for non-adopters and Tk. 402986 for adopters of chemical free technology of pineapple production, respectively (Table 2 and Table 3 ).

In the present study, gross margin was estimated Tk. 161518.2 and Tk. 246700.35 per acre for non-adopters and adopters of chemical free technology of pineapple production, respectively. Per acre net returns of non-adopters and adopters were Tk. 152518.2, and Tk. 238700.34, respectively (Table 4). Net return was higher for adopters of chemical free technology of pineapple while it was lower for non-adopters. Per acre net return of non-adopters was Tk. 152518.2 and for adopters of chemical free technology of pineapple production was estimated Tk. 238700.34, respectively indicating that chemical free pineapple production is more profitable than conventional pineapple production.

The result presented in the Table 4 indicates that pineapple production was profitable in the study area under both chemical based and chemical free production systems because for both systems BCR was greater than 1. BCR is used to measure the efficiency of resource which was applied in the present study on the basis of total cost. BCR was estimated 1.92 for non-adopters implying that Tk. 1.92 would be earned by investing every Tk. 1.00 in conventional pineapple production BCR was estimated 2.45 for adopters implying that Tk. 2.45 would be earned by investing every Tk. 1.00 in chemical free pineapple production.

\subsection{Empirical results of the factors influencing the adoption of chemical free technique of pineapple production}

A Logit model was used to explore the factors influencing the adoption of chemical free pineapple production system of the sample farmers. Six independent variables were identified as major determinants of adopting chemical free technology for producing pineapple in this study. These explanatory variables are age, ethnicity, farm size, farm income, gross margin and training days. All the factors were expected to have a positive impact on adopting chemical free technology of pineapple production.

The result presented that the model was accurate in explaining the factors of adopting chemical free technology of pineapple production. Two out of six variables included in the model were significant in explaining the variation in adopting chemical free technology of pineapple production. These variables were ethnicity and gross margin of the sample farmers in the study area.

Therefore, the estimated equation is as follows:

$\mathrm{Y}=-2.74+0.0767 X_{1}-3.44 X_{2}+0.0083 X_{3}-0.00000675 X_{4}$ $+0.000012 X_{5}+0.19 X_{6}$

The empirical result showed that the coefficient of ethnicity of the respondents has negative value and it was estimated (3.44), which was statistically significant at 1 percent level of significance. It indicates that for Garo ethnicity there was higher probability of adopting chemical free technology of pineapple production.

The result implied that the gross margin of the respondents was positive which was 0.000012 and significant at 5 percent level. This implies that the higher the gross margin of the respondent, the greater the probability that the respondent would adopt chemical free pineapple production. Age of the respondent exhibit positive effect that is, 0.0767 on the probability of adopting alternative technology but this variable was statistically insignificant. The parameter estimates of farm size showed a positive result which is 0.0083 but this variable was statistically insignificant. Farm income represents negative effect and this variable was statistically insignificant. Training days of the respondent exhibits positive effect on the probability of adopting nontoxic production method but this variable was statistically insignificant.

\section{Conclusion}

Ensuring food security and safety for the huge population for pineapple production within the existing scenario of declining soil fertility, decreasing yields, increased and imbalanced use of inorganic fertilizers and pesticides has become a serious challenge for Bangladesh. The majority of farmers had a relatively good attitude toward chemical-free pineapple cultivation, according to the study's findings. Furthermore, the findings showed that ethnicity and the gross margin of the sample farmers had a substantial impact on the adoption of alternative pineapple production technique.The adoption of chemical free pineapple production helped pineapple growers to increase their profit.

\section{References}

Akter K, Majumder S, Islam MA, Noman AU (2018). Exploring Economic Efficiency of Pineapple Production at Madhupur Upazila of Tangail District. Asi. J. of Agri. Ext., Econ. and Socio. 27(4):1-11.

Barnard, CS and Nix, JS (1999). Farm Planning and Control, Cambridge University Press. 600p.

BBS (2013). Yearbook of Agricultural Statistics of Bangladesh, Ministry of Planning, Government of People's Republic of Bangladesh.

BBS (2014). Report on The Productivity Survey of Pineapple Crop, Bangladesh Bureau of Statistics, Statistics and Informatics Division (SID), Ministry of Planning, Government of the People's Republic of Bangladesh.

BBS (2017). Statistical Yearbook of Bangladesh, Bangladesh Bureau of Statistics, Ministry of Planning, Government of the People's Republic of Bangladesh.

BBS (2018). Statistical Yearbook of Bangladesh, Bangladesh Bureau of Statistics, Ministry of Planning, Government of the People's Republic of Bangladesh.

BER (2017). Bangladesh Economic Review, Finance Division, Ministry of Finance, Government of the People's Republic of Bangladesh.

DAE (2016). Department of Agricultural Extension, Ministry of Agriculture, Government of the People's Republic of Bangladesh.

Dillon, JL and Hardaker, JB (1993). Farm management research for small farmer development. FAO, Rome, Italy. 313p.

Doll, PJ, and Orazem, F(1984). Production economics: theory with applications.2nd ed. New York: John Wiley and Sons, Inc. 
Gazi TS (2013). A comparative analysis of Pineapple Mono crop and Pineapple Intercrops of Madhupur area in Tangail district of Bangladesh. M.S. Thesis, Department of Agricultural Economics, Bangladesh Agricultural University, Mymensingh, Bangladesh.

Hasan SS, Ali MA and Khalil MI (2010). Impact of Pineapple Cultivation on the Increased Income of Pineapple Growers. The Agri. 8(2):50-56.

Hoque SS (2015). Impact of sole Pineapple and Intercrops Production on Income and Livelihood of Farmers in some selected areas of Tangail District. M.S. Thesis, Department of Agricultural Economics, Bangladesh Agricultural University, Mymensingh, Bangladesh.

Hossain S (2018). An Economic Analysis on Pineapple Production in some selected Areas of Tangail District. M.S. Thesis, Department of Agricultural Economics, Bangladesh Agricultural University, Mymensingh, Bangladesh.

Hossain, MN (2006). Farmers' Perception on the Effects of Agro-Chemicals on the Environment. M.S. Thesis, Department of Agricultural Extension Education, Bangladesh Agricultural University, Mymensingh, Bangladesh.

Islam S (2015). An Economic study on Practicing IPM technology for producing Bitter Gourd in selected areas of Comilla District. M.S. Thesis, Department of Agricultural Economics, Bangladesh Agricultural University, Mymensingh, Bangladesh.

Joy PP and Sindhu, G( 2012). Diseases of Pineapple (Ananuscomosus): pathogen, symptoms, infections, spread and management. Pineapple Research Station, Vazkhulam, Muvattupuzha, India.

Khalil MI, Ali MA and Hasan SS (2011). Impact of Pineapple Cultivation on the income of pineapple Growers of Madhupur Upazila under Tangail District. M.S. Thesis, Department of Agricultural Extension \& Rural Development, Bangabandhu Sheikh Mujibur Rahman Agricultural University, Gazipur, Bangladesh.

Mursalat, M, Rony, AH, Rahman, MS, Islam, MN and Khan, MS(2013). A critical analysis of artificial fruit ripening: Scientific, Legislative and Socio-Economic Aspects.Chem. Eng. and Sci. Mag., 4(1): 6-12.

Paul MN (2007). Production and Marketing of Pineapple in MadhupurUpazila under Tangail District. M.S. Thesis,
Nishat et al., 2021

Department of Agricultural Marketing, Bangabandhu Sheikh Mujibur Rahman Agricultural University, Gazipur, Bangladesh.

Proshad, R, Islam, MS, Islam, MN, Hossain, MR, Kormoker, T, Islam, MS and Billah, KMM (2018). Promiscuous application of toxic agrochemicals on pineapple: health hazard implications in Bangladesh. F. Res. 2 (2):139-145.

Rahman MM (1994). A Study on Pineapple Marketing in Madhupur Thana under Tangail district. M.S. Thesis, Department of Agricultural Marketing, Bangladesh Agricultural University, Mymensingh, Bangladesh.

Sarkar MR (2014). Socio-economic Study on Safety Compliances and Productivity of small-scale Shrimp Farming under Processing Plant Support and Farmers' own management in coastal regions of Bangladesh. M.S. Thesis, Department of Agricultural Economics, Bangladesh Agricultural University, Mymensingh, Bangladesh.

Sarker MC (1996). A study of pineapple marketing in some selected areas of Moulavi Bazar district. M.S. Thesis, Department of Agricultural Marketing, Bangladesh Agricultural University, Mymensingh, Bangladesh.

Sabahelkhier, KM, Hussain, AS and Ishag, KE (2010). Effect of maturity stage on protein fractionation, in vitro protein digestibility and anti-nutrition factors in pineapple(Ananascomosus) fruit grown in Southern Sudan. Afr.J.Food Sc.4 (8):550-552.

Sriwichailamphan T and Sucharidtham T (2014). Factor Affecting Adoption of Vegetable Growing using organic system: A Case Study of Royal Project Foundation, Thailand. Int. J. of Sci. and Man. Sci. 3(2):1000179.

Sultan T, Islam S, Islam MS, Kamruzzaman M and Kaysar MI (2018). A comparative profitability of pineapplemono crop and pineapple intercrops of Madhupur area in Tangail district of Bangladesh. Asi.-Aus. J. of Fo. Saf. and Sec. 2 (2):56-64.

Toledano BIS (2017). Farmers' Preferences and the factors affecting their decision to improve Maize crops in Mexico. Institute of Sustainability, Universitat Politecnica De Catalunya, Castelldefels, Spain.

The Independent (2019). Chemicals ruining pineapple. http://www.theindependentbd.com/post/12457. August, 23. 